\title{
E a luta continua! \#OCUPATUD0: Potência e dilemas da ação política
}

Ana Luisa Fayet Sallas*

\section{Resumo}

0 presente artigo elabora uma análise dos processos políticos recentes que foram protagonizados por jovens estudantes no contexto das ocupações de escolas do Ensino Médio e universidades públicas em 2016 no Brasil. Analiso esse processo sobre a duas perspectivas: a das relações entre gerações e juventude na contemporaneidade com suas estratégias de ação política diferenciadas das formas convencionais e estabelecidas; e de seu possível vínculo com contexto mais amplo que envolveu o reconhecimento dos jovens e das juventudes como atores políticos, com a criação de dispositivos e instâncias institucionais que promoveram e incentivaram a participação política por meio das Conferências Nacionais de Juventude ocorridas em 2008, 2011 e 2015. Minha hipótese é que os conflitos relacionados ao tema da Educação Pública Superior ganharam centralidade nesse contexto de lutas, bem como sua vinculação a outras bandeiras de reconhecimento como as ligadas às questões raciais, de gênero e LBGT. Procuro recuperar quais foram as demandas gestadas ao longo das Conferências, assinalando o lugar que o tema da Educação Pública Superior ocupou nesse processo e como ganhou centralidade diante do processo regressivo e repressivo desencadeado com o impeachment da Presidenta Dilma Roussef e emergência de grupos políticos que vem colocando o direito à Educação Pública, sob ameaça e objeto de disputa entre grupos/movimentos conservadores como o Escola sem Partido e o Movimento Brasil Livre (MBL).

\section{Palavras-chave}

Movimentos estudantis. Ocupações. Democracia.

\footnotetext{
* Ana Luisa Fayet Sallas é Professora Titular do Programa de Pós-graduação em Sociologia da Universidade Federal do Paraná (UFPR). É Pós-Doutorada em Sociologia no Centro de Sociologia do Colégio do México (2012), Doutora em História pela Universidade Federal do Paraná (1998) e Mestre em Antropologia Social pela Universidade de Brasilia. E-mail: analuisa@ufpr.br.
} 


\section{Abstract}

This paper analyzes recent political processes staged by young students in the context of schools and public universities' occupations in Brazil in 2016. The analysis proceeds along two perspectives: relations between generations and youth in contemporaneity with its particular strategies for political action which differ from more conventional and established forms; and its possible link to a broader context which included recognition of young people as political actors through the creation of dispositives and institutional instances that promoted and stimulated political participation through the Youth National Conferences that took place in 2008, 2011 and 2015. The hypothesis is that conflicts related to Public Undergraduate Education came to occupy a central place in this context of struggles, which was also the case with its linkage to other recognition demands such as those connected with racial, gender and LGBT issues. The paper makes an inventory of the demands produced during these Conferences. It also discusses the role the issue of Public Undergraduate Education has played in this process and how it became crucial in face of the regressive and repressive process unleashed by President Dilma Roussef's impeachment and the emergence of political groups that have been threatening the right to Public Education, turning it into an object of conflict between conservative groups/movements such as Escola sem Partido and Movimento Brasil Livre (MBL).

\section{Keywords}

Student movements. Occupations. Democracy.

\section{Para nos situar}

No final do ano de 2016, ocorreu um movimento político inédito no Brasil com as ocupações de escolas públicas de Ensino Médio e universidades por estudantes mobilizados contra os pacotes de reformas que o governo Temer propunha, atingindo diretamente o sistema educacional brasileiro: a MP 746 e Emenda Constitucional 241/16 - PEC 241. A primeira propunha mudanças na estrutura do Ensino Médio, e a segunda congelar, os investimentos sociais por 20 anos.

A MP 746 redesenha o Ensino Médio, alterando sua carga horária de 800 horas anuais para 1.400, transformando-o em tempo integral. Entre outras coisas, propõe a mudança da estrutura do ensino em áreas de Ciências Naturais, Ciências Humanas e Formação Técnica, tornando facultativas disciplinas como História, Filosofia e Sociologia, além de Artes e Educação 
Física. Naquele momento, a maior crítica dos estudantes secundaristas era o caráter dessa formação, que seria mais técnica, restringindo as opções de uma formação mais crítica e lúdica, além de outros elementos que envolviam a forma autoritária como fora proposta, não levando em conta os elementos já estabelecidos no Plano Nacional de Educação (2014-2024), aprovado em 2014 e assinado pela presidente Dilma Rossef.

Conforme Maria da Glória Gohn (2017), referindo-se aos dados da União Nacional dos Estudantes (UNE), em outubro de 2016, 134 campi universitários e mais de mil escolas e institutos federais estavam ocupados. O Estado do Paraná teve o maior número de escolas estaduais ocupadas (p.100). Segundo a página do Uol Notícias, foram mais de 850 escolas do Ensino Médio ocupadas em todo o Estado do Paraná, de um total de 2.100 da Rede Pública ${ }^{1}$.

A estratégia de luta desenvolvida pelos estudantes secundaristas foi a da ocupação das escolas. Os estudantes universitários recorreram também a esse recurso, contando com um apoio parcial ou expressivo de professores e técnicos das universidades públicas em seus diferentes contextos locais (em alguns, as ocupações se somaram às ações já desencadeadas por técnicos e docentes em greve). Como estratégia de luta, as ocupações não são propriamente novas no âmbito da ação política de diferentes grupos sociais organizados, como indígenas, sem terra, entre outros. A particularidade do fenômeno que ocorreu nas escolas públicas foi a da inserção dessa estratégia das ocupações, de início ainda em 2015, nas escolas públicas de São Paulo².

Os estudantes secundaristas tiveram sua ação política orientada pelo manual elaborado pelos estudantes secundaristas chilenos, que utilizaram essa estratégia de luta durante os anos de 2011, mobilizados pela gratuidade do ensino e pelo passe livre. Esse aspecto é relevante, porque marca os componentes de conectividade e dos translocalismos próprios dessa ação política juvenil. Nesse documento ${ }^{3}$, que foi também utilizado

\footnotetext{
1 Disponível em: <http://www1.folha.uol.com.br/educacao/2016/10/1827222-justicada-ordem-para-estudantes-desocuparem-25-colegios-no-parana.shtml>. Acesso em 25 de setembro de 2017.

${ }^{2}$ Emergiram de um processo de reformulação das escolas (pela separação dos níveis de Ensino Básico e Ensino Médio), além de fatores ligados às denúncias de desvio de recursos da merenda escolar pelo Governador do Estado Geraldo Alkimin.

3 “Como ocupar um Colégio?". Disponível em: https://gremiolivre.wordpress. com/2015/10/21/como-ocupar-um-colegio-versao-online/. Acesso em 11 de setembro de 2017.
} 
por estudantes argentinos e traduzido para o português, destacam-se todos os aspectos envolvendo a ação política, como organização das assembleias, comunicação interna, realização de atividades dentro das ocupações, alimentação, segurança (em que se destacam a necessidade de todos os estudantes da ocupação terem em mãos suas identificações, já que qualquer ação da justiça ou polícia só pode ser feita com a presença do Conselho Tutelar), limpeza, comunicação externa, apoio dos professores, pais, coletivos e comunidade em geral.

Essa estratégia, que orientou e ajudou na mobilização dos estudantes em escolas pelo Brasil todo, teve seguramente um caráter diverso em relação a outros movimentos estudantis, já que especificamente naquele momento foram os estudantes secundaristas que tiveram um papel protagônico em relação aos estudantes universitários, que vieram a realizar as ocupações das universidades públicas em meados de outubro de 2016, quando grande parte das escolas públicas já estava ocupada desde o início daquele mês.

Para alguns analistas, o "despertar"4 da juventude brasileira já havia ocorrido durante as chamadas "Jornadas de Junho de 2013", quando saíram às ruas com seus cartazes de "Não é só por 20 centavos", "Vem pra Rua" e "Saimos do Facebook" e "Agora a revolução é nossa", entre outros slogans 5 . Grande parte das pesquisas que foram realizadas, tentando compreender aquele momento, destacam o caráter heterogêneo e difuso das mobilizações e que funcionou como um balão de ensaio para o que viria a seguir, como as mobilizações "patrióticas" de 2015/2016 contra a corrupção e pela cassação da presidente eleita Dilma Roussef.

Neste ensaio, procuro refletir sobre essa nova geração e sua forma de fazer política marcada pela conectividade e por ser socializada num espaço inovador de participação política institucional que emergiu no marco das Conferências Nacionais de Juventude. Dessa forma, apresento aqui num primeiro momento o conceito sociológico de geração e de culturas juvenis, para finalmente tratar das questões que foram apresentadas pelos jovens nas Conferências Nacionais de Juventude dos anos 2008, 2011 e 2015, em que o tema da Educação Pública Superior ocupou um papel central.

\footnotetext{
${ }^{4}$ No meu ponto de vista, essa ideia de "um despertar" está associada a uma visão limitada dos jovens, desconhendo as suas estratégias de ação política que não estão vinculadas necessariamente a grandes bandeiras políticas. No entanto, vale ressaltar que, nos eventos de junho de 2013, o Movimento Brasileiro do Passe Livre teve um papel protagônico.
}

${ }^{5}$ Vários autores analisaram esse fenômeno, como Gohn (2014; 2017). 


\section{Uma nova geração e uma nova forma de fazer política}

A obra de Carles Feixa “De La Geración@ a la \#Geración - La Juventud em la era Digital" (2015) traz contribuições importantes sobre a forma como podemos compreender as novas gerações e suas formas de ação política. No pensamento sociológico clássico, o conceito de geração elaborado por Mannheim (1927) traz uma reflexão para o estudo das mudanças sociais em que os tempos das biografias e históricos se entrecruzam. Os vínculos geracionais são aqueles marcados por acontecimentos que rompem a continuidade histórica e marcam um "antes" e um "depois" na vida coletiva. Por outro lado, essas descontinuidades são experimentadas por membros de um grupo de idade num ponto formativo, em que o processo de socialização ainda não esteja totalmente concluído, permitindo que essas experiências históricas configurem como "experiências juvenis". (FEIXA, 2015, p. 51-52).

Da reflexão de Mannheim (1927) cabe destacar que, para ele, nem todo novo é a expressão do revolucionário e avançado, já que é possível a existência de jovens com um perfil conservador que convivem num mesmo tempo histórico. Vale lembrar que esse primeiro escrito dele foi elaborado no contexto da emergência da juventude nazista na Alemanha do entreguerras. Ser jovem em um contexto histórico determinado não significa aderir necessariamente às visões mais avançadas expressas em sua época.

No aprofundamento dessa perspectiva de Mannheim, o sociólogo inglês Philip Abrams (1982) propõe vincular o conceito histórico-social de geração ao de identidade. A individualidade e a sociedade se constroem socialmente, havendo a necessidade de se pensar nas relações de interdependência entre essas duas dimensões. Também para ele, a identidade é resultado da consciência do entrelaçamento entre a história individual e a história social. Uma geração no sentido sociológico é o período de tempo durante o qual uma identidade se constrói sobre as bases e recursos de significados que social e historicamente se encontram disponíveis. Assim, as novas gerações criam novas identidades e novas possibilidades de ação.

Conforme assinala Feixa (2015), de comum, Mannhein e Abrams partem de um princípio de que uma nova geração é marcada por descontinuidades do mundo histórico e institucional dominante num determinado momento. Uma outra dimensão associada ao conceito de geração é o de experiência, que está vinculado à ideia de "consciência geracional", que demarca uma 
dimensão reflexiva, em que as relações intergeracionais convertem no domínio de uma elaboração subjetiva ${ }^{6}$.

$\mathrm{Na}$ atualidade, Ulrich Beck e Elizabeth Beck-Gernsheim (2006) propuseram a noção de uma "geração global" - na formulação da ideia das "constelações geracionais cruzadas", já que a experiência da uma geração global, que se globalizou, é, ao mesmo tempo, marcada por profundas diferenças e constrastes, definidos por fatores cosmopolitas. Essas constelações geracionais, segundo esses autores, são demarcadas por três elementos: as gerações das migrações (transnacionais); a geração aprendiz (marcada por processos de precarização do trabalho) e a geração patchwork (marcada por processos de hibridização cultural). Nessas três áreas - demográfica, econômica e cultural - as gerações mais jovens teriam o papel de atuar como barômetro das novas tendências. (FEIXA, 2015, p.6263)

Para Carles Feixa, contemporaneamente, observamos um trânsito geracional do que ele designou como Geração@ para Geração\#. A primeira é a geração da emergência da internet e das redes e que teve uma socialização inicial com games e o acesso a uma educação digital não formal, que prefigurou a cultura de interação que caracteriza a rede. Já a Geração\# é a geração das redes e da web social com o uso intensivo do Facebook, das plataformas de microblogs, como Twiter, num contexto de crise econômica e social. Do ponto de vista tecnológico, a Geração\# supõe um reset das chaves de acesso à sociedade de conhecimento, baseada na tendência à universalização da conectividade e generalização do uso dos celulares e smartphones, supondo assim a deslocalização das conecções (FEIXA, 2014, p. 322).

Para ele, os dilemasdaGeração@com seus desdobramentosintensificados na Geração\# serão demarcados pela presença de alguns elementos:

1. Espaço global versus espaço glocal: se a Geração@ experimentou a globalização do espaço mental e social dos jovens, a Geração\# o está experimentando em espaços mais personalizados, próximos e familiares, com a construção de novos espaços híbridos unindo o local ao global.

\footnotetext{
${ }^{6}$ Essa dimensão reflexiva da experiência geracional associada à questão da identidade é o que temos identificado no contexto da pesquisa coordenada por Simone Meucci - Sentidos e Sentimentos das Ocupações (2016) - que emergiu nas entrevistas realizadas com jovens que participaram ativamente daquele processo.
} 
2. Tempo virtual versus tempo viral: na Geração@ houve um entrelaçamento entre o tempo virtual e os ritmos cotidianos, em que o calendário, o ciclo vital e o tempo histórico assemelhavam-se a um iô-iô flexível, com fases expansivas e contrativas. Já a Geração\# experimenta um tempo viral da mesma forma com as informações que se constroem na rede, marcando alterações nas temporalidades juvenis, combinando transições clássicas com formas intransitivas produzidas pelas culturas juvenis e as formas virais produzidas pela web social.

3. Nomadismo versus translocalismo: se na Geração@ foram experimentadas as identidades nômades, a Geração\# se organiza de forma translocal, marcada pela mobilidade constante, a desvinculação de identidades sociais, culturais e profissionais fixas, o domínio do efêmero jogo de papéis, que leva a mobilidades físicas e virtuais e de novas conectividades (Facebook, Skype, WhatsApp). A cultura juvenil sobrepassa a juventude, tornando possível uma cultura juvenil sem jovens, segundo a expressão de Canevacci (2000).

4. Rede versus rizoma: se a Geração@ participa politicamente através do modelo da "sociedade de rede", a Geração\# o faz através do modelo da "rede social" (CASTELLS, 2012). O rizoma é um ramo subterrâneo com várias gemas que cresce de modo horizontal, criando novas raízes e novos brotos. Foucault e Deleuze usaram esse conceito para analisar as formas de dominação microfísica, capilar e que podem ser utilizadas para interpretar as novas formas de participação e mobilização política dos jovens na contemporaneidade. Nesse sentido, o próprio conceito original passa a ser ressignificando, adquirindo o sentido de estratégias de resistência política. (FEIXA, 2014, p. 323, 327)

Cada um desses elementos tem concorrido de forma diferenciada para a agência dos jovens na construção de novas formas de mobilização e ação política que nos desafia a reelaborar nossos marcos conceituais num horizonte complexo e de intensas transformações.

De toda forma, para além das definições conceituais que utilizamos, compartilho com Carles Feixa a ideia de que existe um jogo de espelhos entre as imagens que cada geração de jovens projeta sobre a sociedade adulta, e o retrato muitas vezes deformado que ela lhes devolve parece manter um rito 
de eterno retorno: nós, adultos, julgamos os jovens à luz de nossa própria juventude. Esse julgamento pode ser a adoção de uma atitude autoritária diante deles, baseada na crença de que o tempo passado foi melhor, ou ainda num outro extremo, uma adulação acrítica, baseada na ideia de que o futuro sempre tem razão. Entre essas visões, é necessário assumir que cada geração vive de forma distinta a aventura de fazer-se adulto.

\section{Culturas juvenis e democracia}

Ao aprofundar a compreensão da relação entre a Geração\# que atuou de forma inovadora e determinada no Brasil com as ocupações das escolas públicas e das universidades, resta contemplar aqui a dimensão identitária que tem marcado de forma significativa essas ações. As reflexões de Rossana Reguillo (2000) sobre as culturas juvenis no final do século XX em suas estratégias políticas de visibilidade e reconhecimento, do meu ponto de vista, seguem vigentes. Para a autora, no mundo contemporâneo, as culturas juvenis marcam: a) uma percepção distinta da política; b) sua percepção do espaço, e c) sua percepção do futuro (marcada por diferenças de gênero, classe, raça). Essas três dimensões irão concorrer para a construção da ação política construída a partir dos seguintes elementos:

1. O debate tem se ampliado para a ideia de uma cidadania "cultural", dimensão que torna visível as lutas políticas de minorias e de excluídos dos circuitos dominantes, no reconhecimento de pertencer a uma comunidade específica.

2. A visibilização se converte em nova estratégia política. Performances que carnavalizam os protestos, a dramatização dos referentes identitários, a imaginação capaz de chamar a atenção dos meios de comunicação, transformando os modos de fazer política.

3. A irrupção na cena política de dimensões da vida privada e cotidiana e a visibilização crescente do discurso da diferença cultural como componente indissociável das democracias modernas.

4. Os debates em torno da cidadania apontam para a necessidade de renomear um conjunto de processos de incorporação e reconhecimento social que não se limitam a pertencer a um território, ao direito do voto e à segurança social, mas se articulam com a reivindicação da diferença cultural como meio de impulsionar a igualdade (REGUILLO, 2013, p.117). 
Se a cidadania se define pelo fazer, é nas práticas o território privilegiado para explorar a participação juvenil, para além dos âmbitos formais. A complexidade de sentidos com que os jovens habitam o espaço público apresenta pistas para entender o futuro de nossas sociedades. Aprofundar o conhecimento sobre as culturas juvenis é fundamental para a construção de um projeto político em que a diferença e a diversidade não sejam instrumento retórico de dominação e de violência.

Identifico nesses elementos o que grande parte das pesquisas sobre o movimento das ocupações tem observado: os jovens estudantes procuraram criar um espaço de ação política distanciado dos partidos políticos convencionais e que, além das demandas pela garantia dos direitos sociais como aqueles que envolviam impactos diretos sobre a da Educação Pública, se vincula a outras demandas, como o direito à diferença, presentes nas reivindicações identitárias de gênero e raciais ${ }^{7}$.

Para Rossana Reguillo, pensar os dilemas que os jovens vivenciam na contemporaneidade e seu papel protagônico num contexto de intensas mudanças sociais requer contemplar três dimensões fundamentais: 1) os processos de precarização-informalização das biografias, as dinâmicas, os circuitos e os imaginários juvenis; 2) a reconfiguração do Estado social e o fortalecimento do Estado punitivo; e 3) o descrédito das instituições modernas - a escola, os partidos políticos, os sindicatos, as empresas -, como garantia de incorporação, de socialização "exitosa" (2013, p.136).

Até o momento, esbocei neste ensaio algumas pistas para o avanço das minhas reflexões: o tema das gerações, da experiência e da identidade articulada às questões das culturas juvenis, que permitem avançar na compreensão daquele movimento político juvenil que foram as ocupações das escolas públicas e universidades em 2016. Na sequência, vamos adentrar o campo da ação política institucional, observar como ele foi constituído e quais foram suas possibilidades e limites como espaço de ação política juvenil.

\footnotetext{
${ }^{7}$ No momento, oriento uma dissertação de mestrado sobre o tema das ocupações e no Grupo de Pesquisa de Pensamento Social, coordenado por Simone Meucci e Alexandro Trindade, temos mais duas dissertações e uma tese de doutorado que contemplam o tema das ocupações das escolas públicas no ano de 2016.
} 


\title{
Juventudes e seu lugar no processo político contemporâneo brasileiro: as Conferências Nacionais de Juventude
}

O primeiro decênio do século XXI no Brasil foi marcado por avanços significativos na constituição de um espaço próprio de institucionalização das políticas públicas para a juventude brasileira representada por mais de 50 milhões de jovens entre 14 a 29 anos. Desde a criação do Conselho Nacional de Juventude, em 2005, da Secretaria Nacional de Juventude, das Conferências Nacionais de Juventude até a promulgação do Estatuto da Juventude em 2013, observou-se um esforço de estabelecimento de uma agenda de participação com os jovens na construção das políticas e de suas prioridades nos vários espaços da sociedade.

Regina Novaes, antropóloga, pesquisadora e primeira presidente do Conselho Nacional de Juventude (2005-2006), observa de forma precisa que:

\begin{abstract}
"Os desafios no reconhecimento dos direitos dos jovens são muitos. O mais difícil de ser superado é a própria dubiedade advinda das contraditórias representações sociais sobre a condição juvenil. Não é exagero afirmar que a sociedade contemporânea é, paradoxalmente, juventudocêntrica, ao mesmo tempo em que é crítica da juventude. Em outras palavras, nos aspectos da vivência pessoal e da consciência coletiva, ser jovem é um estado de espírito, uma dádiva, um dom de um momento passageiro da vida que não deveria passar, por ser o mais interessante e vibrante. Desse modo, ser jovem é ser empreendedor, expressar força, ter ânimo, se aventurar, ser espontâneo, ter uma boa apresentação física, ser viril, se divertir acima de tudo, priorizando o bem viver em detrimento das responsabilidades mesquinhas da vida. Contudo, no âmbito profissional, no aspecto do compromisso cidadão ou no tocante à participação nos processos de tomada de decisão, inclusive nas esferas políticas, ser jovem é residir em um incômodo estado de devir, justificado socialmente como estágio de imaturidade, impulsividade e rebeldia exarcebada. Nesse caso, é possível afirmar que o jovem é aquele que ainda não é, mas que pode ser, ou que será. Em síntese, são dois lados da mesma moeda. Os mesmos estereótipos que constroem um imaginário social de valorização da juventude são aqueles que a impedem de uma participação social plena". (NOVAES, 2006, p.5).
\end{abstract}

Ao destacar os paradoxos da condição juvenil, revela a multiplicidade de formas em que essa condição é efetivamente vivida, que envolve a 
combinação de processos formativos pela escolarização com desenhos de trajetórias no mundo do trabalho, em experimentações e na definição das identidades em processos constantes de mudanças que passam pela sexualidade, pela adesão a diferentes grupos juvenis, pela sociabilidade e participação em diferentes espaços do mundo social. Para Regina Novaes, cinco são os geradores/mobilizadores da participação política juvenil: 1. as apropriações juvenis do ideário ecológico; 2. os novos sentidos do casamento entre "educação e trabalho"; 3 . as novas versões das lutas pelos Direitos Humanos; 4. a arte e cultura na construção do espaço público e 5. os efeitos e potencialidades das novas tecnologias de informação (NOVAES, 2006, p.35).

Esses elementos assinalados pela autora emergiram no âmbito do processo de participação juvenil representado pelas Conferências Nacionais de Juventude que aconteceram entre os anos 2008 a 2015. Foram três grandes conferências marcadas por um processo de participação ativa dos jovens desde a base, orientados por uma metodologia inovadora, em que tiveram papel protagônico, construindo uma forma de participação mais horizontal e criativa. Para a realização da I Conferência Nacional de Juventude, que teve por lema "Levante sua bandeira", foram mobilizadas mais de 400 mil pessoas. Um dos eixos de debates era Juventude, Democracia e Participação. Como um dos elementos estruturantes desse processo estava na indicação dos representantes municipais para a Conferência Nacional, não é de estranhar que os grupos juvenis que estavam organizados (em partidos políticos - $50 \%$ do total dos participantes) $)^{8}$ tivessem um papel de maior representatividade. Esse elemento pode ser constatado pelas definições votadas como prioridades presentes no documento final. A principal bandeira levantada foi a da Luta pela Educação para 22\% dos participantes.

Das 70 Resoluções aprovadas no documento final, a educação superior apareceu em primeiro lugar:

1. Defendemos que a ampliação do investimento em educação é fator imprescindível para construirmos uma educação de qualidade para todos e todas e que consiga contribuir para o desenvolvimento

\footnotetext{
${ }^{8}$ Aqui está um ponto importante a discutir - que vai além do proposto neste artigo - que é sobre os mecanismos de participação em nível local, regional, estadual, nacional. Só chegam no nacional as organizações de base nacional. Com isso, muitas questões/demandas que podem aparecer na base "somem" na Conferência nacional.
} 
do país. Para tanto, defendemos o investimento de $10 \%$ do PIB em educação. Para atingir este percentual reivindicamos o fim da Desvinculação das Receitas da União (DRU) e a derrubada dos vetos ao PNE (Plano Nacional de Educação). Reivindicamos que $14 \%$ dos recursos destinados às Universidades Federais sejam destinados exclusivamente à assistência estudantil por meio da criação de uma rubrica específica. Defendemos também a ampliação dos recursos em assistência estudantil para estudantes do Prouni e para estudantes de baixa renda de universidades privadas. Garantir a transparência e democracia na aplicação dos recursos.

2. Garantir o acesso e permanência dos estudantes excluídos priorizando as cotas, os programas que garantem a inclusão dos jovens ao ensino superior e aperfeiçoamento do Prouni. Expansão e interiorização das universidades públicas (municipais, estaduais e federais) considerando a realidade regional, visando às demandas das comunidades do campo e tradicionais, tendo em vista a ampliação e oferta de cursos noturnos diversificados, bem como a implementação de política de assistência estudantil (restaurante universitário, bolsa permanência, transporte e moradia estudantil) e a valorização dos profissionais de educação.

3. Democracia nas universidades: com eleições paritárias para reitoria, com o fim da lista tríplice, eleições universais para demais unidades acadêmicas e cargos eletivos, composição paritária dos conselhos e espaços decisórios das instituições, e garantia de organização do movimento estudantil com livre transito dos diretores das entidades no âmbito público e privado (2009, p.281).

Mas palavras de Regina Novaes, é preciso compreender esse "ator juvenil" do século XXI em sua relação/e construção das políticas públicas de juventude (distribuitivas, reconhecimento e participação), programas de ações plurais (múltiplas, simultâneas, diferenciadas) assinalando a necessidade de combinar os princípios da igualdade com os da diversidade, que não excluem a construção de uma agenda política com vistas à superação das desigualdades sociais, especialmente ligadas à questão racial e de gênero. (2009, p.14)

No livro elaborado por Mary Castro e Miriam Abramovay (2009), as quais sistematizaram o processo de participação juvenil ocorrido na I 
Conferência Nacional de Juventude bem como o perfil dos participantes, observa-se o seguinte quadro: foram 1.857 participantes respondentes ao questionário realizado durante a conferência, bem como 30 grupos focais com os mais diversos segmentos da sociedade ali representados.

É importante destacar que a grande maioria dos participantes dessa primeira conferência eram jovens, já que $45 \%$ deles estavam na faixa de 19 a 25 anos (feminino - 44,5\% / masculino 46,9\%) e $21,4 \%$ de 26 a 29 anos (feminino - 17,3\% / masculino 24,0\%). Observou-se que do total de participantes 60,5\% eram homens. Quanto à inscrição sexual (heterossexuais - 89,5\%), foram apresentadas algumas alternativas de orientação sexual, além de homossexuais $(4,4 \%)$, bissexuais $(2,4 \%)$. Na autoidentificação em termos raciais, do total dos participantes $45,3 \%$ eram brancos, $32,3 \%$ eram negros, $11,3 \%$ pardo/mestiço, 4,7\% indígena. A grande maioria dos jovens estuda e trabalha $-57.4 \%$; só trabalham - $24,3 \%$ e só estudam $15,2 \%$, e não trabalham nem estudam $-2,4 \%$. Note-se ainda que o nível de escolaridade dos participantes era: Ensino Fundamental - 6,2\%; Ensino Médio - 26,8\%; Ensino Superior Incompleto - 38,2\%; Ensino Superior Completo - 28,8\%. Quanto ao nível de renda individual: menos de $1 \mathrm{SM}-19,7 \%$; 1 a $3 \mathrm{SM}-$ $43,0 \%$; 4 a $6 \mathrm{SM}-21,2 \%$; 7 a $9 \mathrm{SM}-9,4 \%$; 10 ou mais SM $-6,7 \%$.

Em relação à participação política, observou-se o seguinte: partido político - 50\%; movimentos sociais - 31, $1 \%$; movimento estudantil - 30,4\%; ONGS - 26,1\%; instituição religiosa - 24,5\%; redes, foros e coletivos - $15,5 \%$; instituição de estudo e pesquisa - 14,1\%; sindicato - 9,9\%; outra - 9,0\%; não participa de nenhuma organização - 7,9\%. Quanto à participação em movimentos: movimento estudantil - 39\%; movimento secundarista - 37\%. Daqueles que participam de instituição religiosa (24,5\%): são católicos $53,7 \%$ e evangélicos $-17,7 \%$.

Esses dados assim expostos expressam algumas percepções das autoras quanto a um questionamento da apatia e falta de participação dos jovens em comparação com a geração de 1968; um questionamento de estudos que enfatizam as novas formas de participação juvenil - mais horizontais e mais centrados na questão de identidades - que decretam a falência das formas clássicas de participação (movimento estudantil, partidos políticos, sindicais). Puderam observar que longe da existência de universos separados e antagônicos, entre aqueles que lutam pelo "aqui agora" e pelas questões mais gerais referentes aos rumos da sociedade, encontraram a partir da pesquisa na I Conferência que muitos jovens combinam frentes de lutas específicas com debates mais gerais referentes às questões da desigualdade, 
da violência, de gênero, raciais e sexuais.

Ao mesmo tempo, verificam a emergência desse jovem individualista (mas não atomizado), na medida em que consideram o pessoal como político fazendo um trânsito entre questões vividas individualmente e a luta por mudanças no plano coletivo, como questões de racismo, sexismo, homofobia, emprego decente, educação pública de qualidade (CASTRO, 2009, p. 63).

A II Conferência Nacional de Juventude de 2011 teve por lema Conquistar Direitos Desenvolver o Brasil! No documento final com as propostas aprovadas, aparece no Eixo 1: Desenvolvimento Integral o tema da Educação Inclusiva em primeiro lugar e o direito à Educação Superior em segundo lugar, como demanda específica do aumento de vagas no sistema público e concomitantemente a interiorização das vagas, políticas de acesso e permanência, cotas e a extinção do vestibular como forma de acesso.

Já no documento-base que orientou a temática da Educação para a realização da III Conferência Nacional de Juventude em 2015, que teve por lema "As várias formas de mudar o Brasil", podemos observar os seguintes aspectos que o orientaram:

- A pesquisa Agenda Juventude Brasil: Pesquisa Nacional sobre Perfil e Opinião dos Jovens Brasileiros 2013, realizada pela Secretaria Nacional de Juventude (SNJ), em 2013, aponta que os/as jovens brasileiros/ as nutrem grandes expectativas sobre suas trajetórias educativas. O estudo indica que $42 \%$ dos/as pesquisados/as depositam seus sonhos de realização na construção de trajetórias educativas mais longas, crendo que suas vidas vão melhorar porque terão melhores credenciais educativas e mais condições de inserção no mundo do trabalho. O estudo mostra, ainda, que $63 \%$ reconhecem a "possibilidade de estudo" como o que há de mais positivo no Brasil. Ao mesmo tempo, 98\% dos jovens acham que a educação é um desafio para o país, enquanto $23 \%$ acreditam que o tema é preocupante, ficando atrás apenas de questões como violência, emprego e saúde.

- Expansão do Ensino Superior pelo aumento do número de matrículas. Em 1994, as matrículas em cursos presenciais no ensino superior brasileiro somavam pouco mais de 1,6 milhão. Em 2004, esse número saltou para 4,1 milhões e, em 2013, para 6,1 milhões, reflexo do esforço empreendido. 
- Crescimento expressivo da rede pública, em especial nas cidades do interior do Brasil (REUNI). No entanto, as instituições privadas continuam sendo as principais ofertantes de vagas no ensino superior brasileiro, como se observa na Tabela abaixo com o total das matrículas em cursos presenciais por organização acadêmica entre 2004-2013 (p. 40 do documento-base):

\begin{tabular}{|l|c|c|c|c|}
\hline & $\mathbf{2 0 0 4}$ & $\mathbf{2 0 1 3}$ & $\begin{array}{c}\text { Crescimento } \\
\text { Total }\end{array}$ & $\begin{array}{c}\text { Crescimento } \\
\text { em \% }\end{array}$ \\
\hline TOTAL & 4.163 .733 & 6.152 .405 & 1.988 .672 & 47,8 \\
\hline PÚBLICO & 1.178 .328 & 1.777 .974 & 599.646 & 50,9 \\
\hline FEDERAL & 574.584 & 1.045 .507 & 470.923 & 82,0 \\
\hline ESTADUAL & 471.661 & 557.588 & 85.927 & 18,2 \\
\hline MUNICIPAL & 132.083 & 174.879 & 42.796 & 32,4 \\
\hline PRIVADO & 2.985 .405 & 4.374 .431 & 1.389 .026 & 46,5 \\
\hline
\end{tabular}

Fonte: Elaboração própria, a partir de dados do Censo Escolar - Ensino Superior, INEP/MEC.

- Papel da sociedade civil organizada no processo de democratização do acesso e inclusão social nas universidades devido à Lei 12.711/2012, que instituiu a política de reserva de vagas em universidades e institutos federais de educação, ciência e tecnologia. "Lei de Cotas", a iniciativa garante a reserva de $50 \%$ das matrículas em todos os cursos e turnos para candidatos/as egressos/as do ensino médio público, contemplando um percentual de vagas específicas para jovens de baixa renda, de negros/as e indígenas.

- Programa Universidade Para Todos (ProUni): Implementado pelo governo federal em 2005, o ProUni tem como finalidade a concessão de bolsas de estudo para que jovens de baixa renda acessem cursos de graduação oferecidos por instituições de ensino superior privadas, que, em troca, recebem isenções fiscais de tributos que antes recolhiam. Segundo dados do Ministério da Educação, até o processo seletivo do segundo semestre de 2014, mais de 1,4 milhão de estudantes tinham sido contemplados/as pela iniciativa, sendo $70 \%$ com bolsas integrais de estudo.

- A Portaria MEC no. 389, de 9 de maio de 2013, cria o Programa de Bolsa Permanência, destinado à concessão de bolsas a estudantes de 
graduação de instituições federais de ensino superior, em situação de vulnerabilidade socioeconômica, com a finalidade de minimizar as desigualdades sociais, étnico-raciais e contribuir para a sua permanência e diplomação.

- A partir desses resultados, é possível afirmar que a atual geração de jovens brasileiros/as experimenta os paradoxos de uma sociedade que, nos últimos 20 anos, ampliou as oportunidades educacionais para o conjunto da população, estendendo direitos e condições de acesso à educação básica - especialmente no que se refere ao ensino fundamental e médio - e, mais recentemente, ao ensino superior, sem, contudo, equacionar o conjunto de questões que afetam, de modo desigual, as possibilidades de os/as jovens terem uma formação de qualidade.

- Nesse sentido, o processo de democratização e de inclusão social na universidade deve ser analisado também em termos dos cursos e do tipo de universidade (pública ou privada) acessada pelos/as jovens. Há, ainda, necessidade de romper com ciclos de reprodução de privilégios historicamente consolidados no país, que reservaram aos grupos dominantes o acesso a determinadas carreiras e instituições.

- Proposta de destinação de 10\% do PIB para a Educação. Em 2014, a presidente eleita Dilma Roussef sancionou o PNE (Plano Nacional de Eduação - 2014-2024). Nos primeiros cinco anos - 7\% do PIB e nos seguintes $10 \%$. Essa meta tem sido bandeira de luta de grupos juvenis e de movimentos sociais associada a demandas de melhoria da qualidade da educação básica.

- O que é essencial de ser aprendido na escola? Não há consenso. De um lado existem aqueles que advogam que a escola deve preparar os jovens dentro de parâmetros de eficiência e competitividade, apresentando resultados mensuráveis. De outro lado, há uma tendência à formulação de uma visão mais crítica da educação, fundada nos pressupostos de uma educação capaz de tratar das questões relativas aos processos de reprodução das desigualdades sociais, capaz de construir espaços de participação democrática, dos direitos humanos e do respeito à diversidade racial, de gênero, sexual... 
Da leitura desses pontos que aqui destaco, observa-se que é no debate sobre o Ensino Médio que essas visões antagônicas se apresentaram com mais força, como podemos notar pelas propostas de Reforma do Ensino Médio, polarizadas nas perpectivas a partir de movimentos como o da "Escola sem Partido" e o "Movimento Brasil Livre".

No documento com a Resolução Final da 3@ Conferência aparece a educação, cujo teor é o seguinte: "Reformulação do Ensino Básico e Médio desde a matriz curricular à formação dos professores, democratizando e humanizando as escolas, incluindo debates como gênero, igualdade, justiça social e liberdade; ampliando a carga horária de disciplinas tais como: filosofia, sociologia e história, possibilitando, assim, o senso crítico e político dos estudantes". (2016, p. 9 - negrito da autora). Cabe destacar que essa demanda já figura no primeiro item do documento final com as propostas aprovadas na II Conferência Nacional de Juventude.

Da leitura desse documento e no olhar aos eventos que ocorreram em setembro de 2016, logo após a posse de Temer, percebe-se com clareza os campos em disputa com relação às propostas de Reformulação do Ensino Médio apresentadas por ele quase que imediatamente à tomada de poder, completamente distante daquilo que fora pactuado durante um processo intenso de participação e mobilização dos atores juvenis durante a Conferência de 2015. A hegemonia em torno da Educação Pública revela-se um campo de disputa e de intensa luta política.

É interessante observar que, em outubro de 2016, o Programa Porvir ${ }^{10}$ divulgou sua pesquisa "Nossa Escola em (Re) Construção", com o objetivo de apresentar o que os jovens pensam da Escola e como gostariam que ela fosse. Tiveram a resposta de 132 mil jovens entre 13 a 21 anos de idade

\footnotetext{
${ }^{9}$ O Movimento Brasil Livre é uma organização multinacional, financiada pela Atlas Network, que desenvolve ações no marco de uma agenda "liberal" em vários países da América Latina com organizações de "Estudantes pela Liberdade". Ver matéria sobre esse tema em originalmente publicado na Agência Pública. Disponível em: <https://www.cartacapital. com.br/ politica/a-nova-roupa-da-direita-4795.html>. Acesso em 19 julho de 2017.

${ }^{10}$ O Programa Porvir é uma iniciativa do Instituto Inspirare, uma organização não governamental, que tem por missão desenvolver uma "Educação Integral Inovadora". É dirigido pela família Gradin, com sede em São Paulo. Foi fundado em 2011. Segundo informação em seu site http:/ / inspirare.org.br/category/ porvir, ele é mantido integralmente com recursos da família Gradin. Acesso em 10 de agosto de 2017.
} 
de diferentes regiões do Brasil, mas predominam os respondentes da região Sudeste. Vários resultados ali presentes expressam a necessidade de mudanças nas escolas em termos de sua infraestrutura, da estrutura curricular, da compatibilização em formação profissional e formação de laços e acolhimento.

Essa pesquisa é interessante porque assinala pontos importantes quando se colocam as questões de reformulação da atual estrutura do Ensino Médio. A principal é que as mudanças são necessárias, mas elas não podem ser realizadas sem que envolvam diretamente setores da sociedade civil que atuam no campo educacional de forma ativa com estudantes, professores, pesquisadores da área e outros atores sociais envolvidos com o tema. É fundamental ouvir os jovens e, sobretudo, levar em conta o que eles têm a dizer sobre o seu cotidiano de vida nas escolas e universidades, numa situação em que seu agenciamento passou a ser reconhecido no espaço da vida pública e política no seu mais amplo sentido.

\section{Para encerrar}

Creio que é interessante analisar muito brevemente a Sinopse do Censo da Educação Superior de 2015. Temos do total de matrículas em Curso de Graduação, Presenciais e à Distância a seguinte situação: total 8.027.297; Bacharelado (5.516.151); Licenciatura (1.471.930); Tecnólogo (1.010.142). Desse total, temos 6.075.152 em instituições privadas e apenas $1.952 .145 \mathrm{em}$ públicas (Federal, Estadual e Municipal). Ou seja, praticamente $80 \%$ das matrículas estão em instituições privadas. Embora a Educação apareça nos discursos como uma expressão generalizada e unânime de solução para os problemas do país, ela tem-se mantido como um excelente negócio.

Esses números em confronto com as demandas elecandas nas Conferências Nacionais de Juventude ressaltam o fosso existente na sociedade brasileira na atualidade de cumprir com as metas estabelecidas em 2014 pelo PNE, já que as mudanças em curso no Ensino Médio e na Universidade Pública seguem avançando numa direção em que pouco restará de uma agenda de demandas por acesso e democratização da Educação que foram construídas de forma democrática e participativa por jovens de todos os setores sociais da nossa sociedade. Por outro lado, revelam esse aprendizado que vem criando outro patamar das experiências políticas e das formas de participação juvenil para a construção de uma sociedade que, no momento, transforma a palavra democracia numa 
miragem.

A complexidade da situação contemporânea exige manter o âmbito da cultura e da comunicação articulado ao campo da reflexão e da ação política. Essa articulação será encontrada no centro das mobilizações juvenis, como as ocupações de 2016, em que, por um lado, o uso das redes sociais, Facebook, Whatsapp teve um papel importante no ativismo político desencadeado, e, ao mesmo tempo, permitiu a percepção de que os jovens haviam também borrado as fronteiras entre o público e o privado, entre o subjetivo, o pessoal, as emoções e o cotidiano em sua ação política. Longe de se constituírem como dimensões separadas, elas emergem indissociadas. Assim como as feministas avançaram em suas mobilizações ao proclamarem que o "pessoal é político", os jovens estudantes do Ensino Médio que participaram das ocupações nas escolas públicas em 2016 viveram a experiência de luta e de derrota, mas descobrindo numa dimensão viva e reflexiva suas identidades, lugares de vida e de sentido. Se estou correta na hipótese que orientou minhas reflexões, foi aquele ambiente criado de participação ao longo da última década e meia que permitiu a gestação de novos atores ocupados de fato com suas vidas, sua escola, seu futuro.

\section{Referências}

CASTRO, Mary Garcia; ABRAMOVAY, Miriam. (2009). Quebrando mitos: juventude, participação e políticas. Perfil, percepções e recomendações dos participantes da $1 a$ Conferência Nacional de Políticas Públicas de Juventude. Brasilia, RITLA.

FEIXA, Carles.

(2014). De la Generación@a la \#Generación - La juventude enla era digital. Barcelona, NedEdiciones.

GOHN, Maria da Glória.

(2017). Manifestações e protestos no Brasil: correntes e contracorrentes na atualidade. São Paulo, Cortez.

NOVAES, Regina, CARA, Daniel, SILVA, Danilo, PAPA, Fernandahttp://portal.inep.gov.br/ web/guest/sinopses-estatisticas-da-educacaosuperior (Orgs.)

(2006). Política Nacional de Juventude: diretrizes e perspectivas. São Paulo, Conselho
Nacional de Juventude / Fundação Friedrich Ebert.

REGUILL0, Rossana.

(2006). Emergencia de culturas juveniles Estrategiasdel desencanto. Colombia, Grupo Editorial Norma.

REGUILL0, Rossana.

(2015). Culturas Juveniles - Formas políticas del desencanto. Buenos Aires, SigloVeintiuno Editores.

INSTITUTO NACIONAL DE EDUCAÇÃO (INEP) (2016). Sinopse Estatística da Educação Superior 2015. [Atualizado em 20/10/2016]. http:// portal.inep.gov.br/web/guest/sinopsesestatisticas-da-educacao-superior. Acesso em 14 julho de 2017.

DIREITOS DA JUVENTUDE - Subsídios para um debate.

(2015).3@ Conferência Nacional de Juventude. Disponivel em: http://juventude.gov.br/ 
articles/participatorio/0011/0369/secaoII juventude_e_educacao_0K.pdf >. Acesso em 12 julho de 2017.

RELATÓRIO FINAL NOSSA ESCOLA EM (RE) CONSTRUÇÃO - Program Porvir (2016). Disponivel em: http:// s3.amazonaws.com/porvir/wpcontent/uploads/2016/10/06150937/ RelatorioCompleto

NossaEscolaEmReConstrucao_Final.pdf>. Acesso em 4 de outubro de 2016.
RESOLUÇÃO FINAL DA $3^{a}$ CONFERÊNCIA NACIONAL DE JUVENTUDE.

(2016). "As várias formas de mudar o Brasil" - Prioridades aprovadas na etapa nacional. Conselho Nacional da Juventude. Brasília. Disponivel em:<http://juventude.gov.br/ articles/participatorio/0017/5777/relatoriofinal-3-conferencia.pdf $>$. Acesso em 12 julho de 2017.

Recebido em

janeiro de 2017

Aprovado em

maio de 2017 